\title{
Prisgitt ekspertene
}

\author{
Ryggmargslidelse. Jeg visste \\ knapt hva en ryggmarg var før min \\ egen plutselig var skadet. Du er \\ prisgitt den behandlingen du får \\ av dem som besitter kunnskapen \\ som så smertelig angår deg. \\ Men med kunnskap kommer også \\ et ansvar om formidling.
}

Høsten 2009 fikk jeg en epiduralbedøvelse i forbindelse med et inngrep for å flytte bein fra hoftekammen til nedre del av tibia. Bedøvelsen gikk aldri ut igjen, og jeg ble varig lammet fra navlen og ned. Noe som slo meg gjentatte ganger gjennom tiden som fulgte, både i primærrehabiliteringen og ved senere relaterte skader, er hvor prisgitt man som «vanlig borger» er dem som sitter med informasjon og kunnskap om diagnosen som skal prege ens liv. Hvordan sakkyndige formidler denne kunnskapen påvirker hele prosessen for pasienten under en skade- eller sykdomsperiode, og kan være avgjørende for evnen til å håndtere egen livssituasjon.

Første møte med helsesystemet kan være overveldende, spesielt om man er i en sårbar skadesituasjon. En opplevd samlebåndstilstand fører til et usymmetrisk maktforhold, hvor «det kunnskapsløse individet» møter det organiserte og velinformerte systemet. Å være en enkeltpasient i en tilsynelatende uendelig pasientrekke, kan være utfordrende på mange måter. Å møte et system med autoriteter der maktforholdet i utgangspunktet oppleves ulikt, kan i seg selv være en enorm barriere. Med individuell kontakt og oppfølging kan utfordringene for øvrig føles mer overkommelige. I India er det gjennomført flere prosjekter der personer med funksjonsnedsettelse er blitt utstyrt med mobiltelefon. Denne skulle brukes til å ringe helsepersonell om pasienter eller pårørende hadde spørsmål rundt skader, eller det oppsto tilleggsproblematikk. Resultatene har vært forbedret livskvalitet - ikke fordi de ble friskere, men fordi de fikk svar på spørsmålene de ellers ville ha brent inne med. Verdien av trygghet kan ikke overvurderes. Uavhengig av størrelsen på systemet rundt avgjør helsepersonell selv hvordan de opptrer i møte med den enkelte pasient. Å se pasienten som et enkeltindivid kan være brikken som må på plass for å sikre nødvendig trygghet, og som dermed utgjør grunnsteinen for videre behandling.

Kunnskap er makt og med makt følger ansvar. En leges formidlingsevne kan være avgjørende for pasientens evne til å takle og leve med sin nye helsetilstand. Det kan være vanskelig å forholde seg rasjonelt og nyansert til problemstillinger man aldri ønsket å måtte leve med. En aktiv innsats på kommunikasjonsfeltet kan likevel være et verdifullt bidrag til å redusere gapet mellom pasientens forventning og håp om å bli helt frisk, og helsevesenets handlingsrom for å helbrede.

Å planlegge et liv innebærer at man må ta utgangspunkt i sine fysiske forutsetninger. For å kunne tenke realistisk må man ha en virkelighetsnær forståelse av egen situasjon. Så mye vil alltid være usikkert i livet, men følelsen av kontroll kan likevel økes ved bevissthet rundt denne usikkerheten. Til tider stemmer ikke verden overens med personlige visjoner.
Av og til vil drømmer knuses eller håp svekkes. Ved alvorlig sykdom eller skade kan det hende at det vil skje, uansett hva man gjør, og spørsmålet da er om pasienten får mulighet til å forberede seg mentalt. Å pakke inn budskap, gå rundt grøten, holde tilbake ubehagelig informasjon eller unnlate å fortelle hele sannheten kan være virkemidler for å gjøre vanskelige situasjoner lettere å håndtere, både for pasienter og for helsepersonell. De samme virkemidlene kan også virke motsatt - og i stedet fostre flere spørsmål, mer frykt og større usikkerhet. AErlighet er beslektet med respekt, anerkjennelse og integritet. vet man ikke sikkert hva som kan bli utfallet, kan det være hensiktsmessig å si hva man vet og ikke vet - heller enn ikke å si noe. En pasient vil alltid ha en subjektiv oppfatning av situasjonen, og hvorvidt helsepersonell kan bidra med relevant informasjon eller kvalifisert gjetning, kan i stor grad bidra til om dette subjektive bildet bygger på et smalt eller et bredt erfaringsgrunnlag. Erlighet hos helsepersonell bidrar til realisme hos pasienten.

En ryggmargsskade kan være så liten, og likevel så ufattelig stor. A takle utfordringene som følger krever en leges medmenneskelighet, fagkunnskap og ærlighet. Jeg som pasient vil inkluderes i prosessen som skal prege meg resten av livet, og jeg vil vite hva som skjer.

Se meg. Snakk til meg. Og vær ærlig. Jeg er like oppegående som alle andre - jeg har bare satt meg ned.

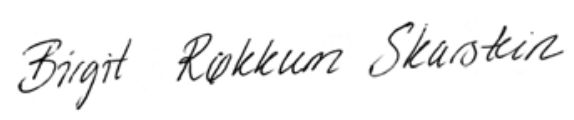

